\title{
ART AND SPIRITUALITY. EXPLORED ON THE LEVELS OF EXPERIENCE, MEANING AND RESEARCH
}

\author{
JOHAN GOUD* \\ Utrecht University
}

\begin{abstract}
The area where literature, art, music, religion, spirituality, and philosophy split off from, run parallel to each other, and merge again is like a delta. This essay explores the complex interrelations between art and spirituality on three levels. First on the level of spiritual experience, exemplified by experiences of the art of still life (the painter Morandi, the poet Kopland). On the second level, several questions about meaning are analyzed, beginning with the question of meaning posed by the work of art itself. Both art and spirituality presuppose an open and receptive attitude. In philosophical reflections on the meaning of art, some aim primarily at its relevance for our insight into the reality of things, people, and animals, while others are more concerned with its significance for human action. Thirdly, some problems on the level of research are discussed. Research invites us to come to a critical relativization of what we have seen, heard, or read and also allows us to see that the often presupposed 'immediacy' of our experience is in fact mediated by pre-given schemes and habits. Three reasons are given to answer the question why it is meaningful to research these mediations and to search for the authentic meanings of art works (in particular works of literature) themselves.
\end{abstract}

KEYWORDS: Spirituality, art and literature, experience, meaning, research

The area where literature, art, music, religion, spirituality, and philosophy split off from, run parallel to each other, and merge again is a delta. There is no point at all in strongly pointing out that music is not about anything but notes, that art is not about anything but forms, and literature is not about anything but language. It is not only that these forms of art are inspired by each other and learn from each other. More than anything else, the context in which they are found gives them energy in all kinds of ways-including, though not solely, energy that has withdrawn from religions and philosophies. Biographers research such contexts; artists speak about them in interviews; readers, viewers, and listeners place the work of art within their own horizon of understanding. The poem is a living sperm cell, the Dutch author Simon Vestdijk writes. It is a small, vital organism

* JOHAN GOUD (PhD 1984, University of Leiden) is professor emeritus in the field of theological and philosophical aesthetics at Utrecht University. Email: J.F.Goud@uu.nl. 
that develops a separate structure, resists other cells and organisms but is also nourished by its environment in countless ways.

This essay explores the complex flow area of art and spirituality-two terms under which I subsume all the above-mentioned streams. I prefer the term spirituality over religion here. The term 'religion' inevitably brings to mind certain traditions and the doctrines that they include. The expressiveness of art can be linked to that, but in many cases it moves on the broad terrain of spirituality outside the bounds of specific religions. In this chapter, I will explore this spirituality from three perspectives: that of experience, the question of meaning, and research.

\section{Experience}

It is especially on the level of experience that an explanation can be found for the enthusiastic and wide interest in the link between spirituality and art. The spiritual experience of art comes to the fore in all kinds of waysin, for example, the Hart \& Ziel (Heart \& Soul) broadcasts on Dutch classical music radio, NPO 4, in the large numbers of people who come to view relics and Rothko, in films like those by Lars von Trier, in the popularity of authors like Reve and Wieringa, in the popularity of Bach's Passions and The Passion. The spiritual experience is a multiform phenomenon that is difficult to define. In our current culture, this experience has become a very loose, open, and eclectic phenomenon. A definition of spirituality that I proposed and defended elsewhere seems to be fitting and of use here as well: 'the basic attitude towards liminal questions (concerning death, suffering, guilt, etc.), that determines more concrete decisions and actions' (Goud 2011: 113-114).

The arts give expression to this basic spiritual attitude in different ways. Dance, as pointed out by the religious studies scholar G. van der Leeuw, looks for an original balance between the human being and the cosmos. Theatre stages the genesis and development of the basic spiritual attitude by portraying interactions and intrigues between people. Music seems able to do justice, in a way that no other art form can, to what is inexpressible but at the same time moves and touches people in the very depths of their being. The visual arts and poetry have the ability to concretize symbols and, conversely, to turn ordinary things into symbols-in other words, to make them unusual and to raise them above the levelling march of time.

Scholars in the field of theological aesthetics are sometimes inclined in their interpretation of this symbolizing effect to go further than required, in my view. They give a sacramental explanation to works of art, as if certain works of art express the incarnation or an epiphany of the divine. Such an interpretation adds nothing to our insight into the expressiveness of literature and art. In addition, it often goes along with a limitation to explicitly 
religious works of art that, according to Patrick Sherry in a handbook on Catholicism, play 'a role analogous to a sacrament', 'for they may be signs and likenesses of the divine' (Sherry 2007: 475). In this respect, I feel at home in the cultural-theological view advanced by Paul Tillich (1886-1965). In his criticism of such approaches, he underscores the space of human experience in which works of art can, through their expressive ability, erect signs of 'what precedes us unconditionally'. And what precedes us unconditionally can be filled in in a number of different ways, as fits the multiform nature of spiritual experience. ${ }^{1}$ Viewed in this light, traditional oppositions between what is secular and what is holy, between what is profane and what is sacred, or between 'enchanted', 'disenchanted', and 're-enchanted' play a secondary role. According to Tillich, unbelievers often succeed much better than recognised religious artists do in evoking the religious 'depth dimension' in their work. It is an observation that I have found confirmed in my own experience-so frequently, in fact, that I am inclined to relativise the opposition between belief and unbelief.

The 'art of the still life' can serve as an example of a spiritual experience of art. I wrote a meditative text (on the website of the Remonstrant church) that introduces links between the still lifes of Morandi, the poetry of Rutger Kopland, and a well-known statement by the biblical writer Qoheleth in his reflections about time.

The Catholic theologian Anton de Wit wrote a short theology of ordinary things (2010). He reflects in that book on ordinary things that, upon closer inspection, conceal worlds of meaning in themselves: the introduction round, the train trip, the animated film, space, the late summer sun, bonfires, walking, and so on. It is a way of doing theology that fascinates me extremely because, among other things, it teaches us to wonder how those things around us have become so inconspicuous and so ordinary. After all, they did not start out that way.

The painter Giorgio Morandi (1890-1964) concentrated his whole life on collecting the most ordinary things-bottles, cans, and boxes, in constantly new combinations and hues. Using nothing but some colors and lines he attempted to capture them and to set down their constantly fleeting meaning. It is as if he himself wanted to set up a monument to bottles without time and space. It is a paradox. Without Morandi's accurate, endlessly repeated observation, those still lifes would not be there. But it is as if he wanted to erase himself, the painting observer-to make room for those bottles, cans, and boxes. His still lifes are meditative paintings. It is not for

1 I realise that this loose spiritual application is not entirely in line with Tillich's intentions. He starts with reflections about the biblical God and wants to show that all art can be a place to find God (Stoker 2019: 256ff). 
nothing that Morandi is called a painting monk. Always in the same city, usually at the same spot, looking, as it were, with spiritual eyes, to show the eternal in those dead and unmoving objects.

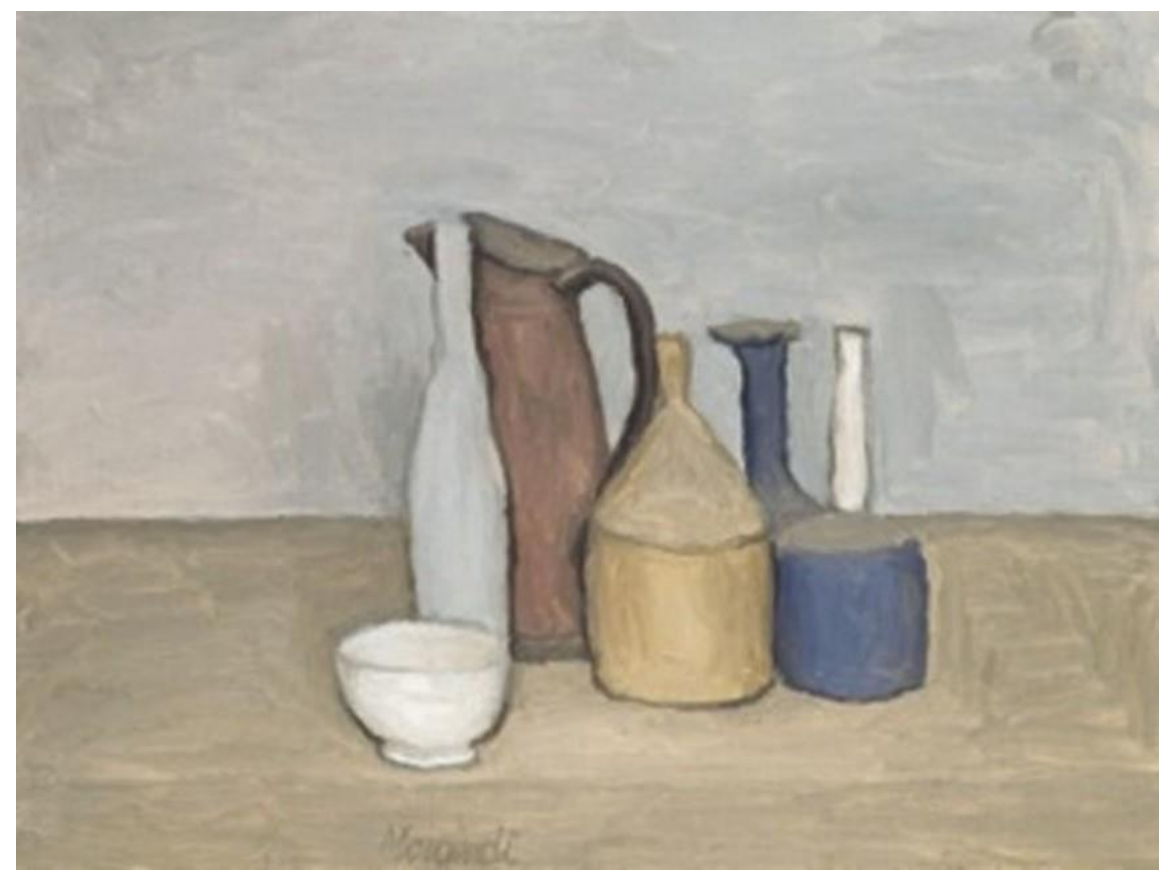

Rutger Kopland (1934-2012) wanted to achieve something similar in his poetic still lifes. In many of his poems, he was attempting to evoke the presence of what was not or no longer was. This is what he does, for example, in his cycle, 'Dankzij de dingen' (Thanks to the Things), five poems in which he accentuates morning, afternoon, evening, and night in his grandparents' home. He reflects on the things of then, which were not yet things then, the life they shared in, the meaning they had, and-in the same breath-our own fleetingness that has caused us to lose them with their life and their meaning. But he also points to the happiness that flows through the poet when he again, so to speak, 'sees' these things. He calls it a 'revelation': 'I sought the key to the cellar in my brain where a still life had to be stored somewhere of which I had briefly gotten a glimpse' (Kopland 1995: 80). ${ }^{2}$

It is a wonderful feeling of happiness, as if it worked for a brief moment to stop time and to allow one to go back in time. It goes contrary to the wistfulness that seems to inevitably arise when one thinks back on one's grandopgeslagen, waarvan ik even een glimp had opgevangen.' 
parents' home and things, the things that pass away because one passes away oneself. For one fleeting moment, something else is possible, the reversal in the still life, "in which the light, the smells, the sounds lose their meaning, and that what is seen, heard, and smelled refers to itself, withdraws into eternity' (Kopland 1995: 83). ${ }^{3}$ The still life briefly triumphs over the disappearance of all things and of oneself, for the viewer is the one who sees everything and experiences everything and registers everything.

it is death that searches for

words for the moment at which

$\mathrm{I}$, and whatever he says,

it is me.

I like to read the Bible in the same spirit—as a book that practices the art of the still life. I then imagine God looking at things and people, including or precisely at the most impossible things, with the eyes of Morandi and Kopland: the things, the animals, and the people who remain invisible because no one sees them. It is one of the few things the skeptical Preacher (of the Book of Ecclesiastes) seems to know, despite all his doubts: God recalls what has passed and takes pleasure in the intangible.

\section{Questions about Meaning}

We will leave experience behind now, as we attempt to make explicit what meanings works of art present to us, or, better: what questions about meaning they confront us with. After all, prior to all critical mirrorings (see the following section), that is where the experience of art begins. It begins in the encounter with the work of art as Other, which withdraws from my judgments and looks at me, reads me before I myself begin to read, perhaps even gives me a task.

Consequently, I will search for the question that is asked me. Religion and theology on the one hand and art and literature on the other come very close to each other on the level of this question. In this respect, they appear to resemble each other-at least, as long as they remain faithful to what makes them what they are. Both are directed at evasive or transcendent meanings, or, to express it in a less vague way, at phenomena whose meaning is both present and absent at the same time. They therefore presuppose an open and questioning attitude and resist the 'premature attempts at the closure of meanings', as the theologian T.J. Gorringe remarks gezien gehoord en geroken naar zichzelf gaat verwijzen, zich terugtrekt in eeuwigheid.' 
(Gorringe 2011: 192). By exchanging experiences and insights, they can reinforce each other in this attitude. They then help each other to remain questioning disciplines and to keep the dimension of interiority open that is blocked not only by religious dogmatism but also by 'parascientific' criticism of religion (to cite the thesis of Marilynn Robinson in her Absence of Mind which was published in 2010). To know for certain whether it is religiously or atheistically oriented puts an end to the ability to ask questions and whatever else is part of that: the openness, the admiration, perhaps even the reverence.

Let me take one critical step back, for what I have argued up to this point is still relatively general and could have the effect of obscuring some important aspects. Should we approach art and literature on the basis of a religious interest, as theologians or scholars researching spirituality? If so, under what circumstances is that allowed? Paul Tillich, whom we mentioned above, opined that it was possible to label works of art as 'Protestant' based on formal characteristics of style. Gorringe, whom we mentioned above, places the emphasis more on the viewer or reader. Indeed, in his reflections on art, Gorringe chooses to be an explicitly Christian theologian, but he is aware that this choice lies on the level of reception aesthetics, i. e., conceived from the perspective of the theological viewer. But both theologians underscore that the artist's view of life adds nothing in this respect. That is correct as well. An artist must, above all else, want to be authentic and to resist the omnipresent and always threatening corruption of our consciousness (whether that comes from the religious or the non-religious side).

I repeat my question. Under what circumstances can we view literature and art as sources of religious insight and as giving spiritual depth-if that is, in principle, allowed. There are many studies about individual artists (Dostoyevsky, Barnet Newman, Lucebert, Andy Warhol, to mention a few) with appealing results and written conclusions. But can the question also be answered in a more general sense? In my view, this is certainly the case, even if some caution is required here. I will use literature to argue my case, but I do think that a similar argument can be applied to art in a broader sense.

In my view, principial objections to a philosophical or religious reading of literary texts are not convincing, as long as the particular requirements set by the reading of narrative and fictional texts are respected. A great deal can be said for such a reading. Many researchers ascribe an independent philosophical function to literature. Here, some aim primarily at the relevance of literature for our insight into the reality of things, people, and animals, while others are more concerned with the significance of literature 
for human action. The first group is more interested in theoretical ontology, the second in practical ethics.

The great Greek thinker Aristotle (384-322 B.C.) places himself in the first group when he argues that tragedians, unlike historians, deal with human existence on a universal level. They do not describe facts but investigate possibilities of existence. In the same spirit, the literary theorist $\mathrm{S}$. Dresden (1914-2002) writes that great novels penetrate 'right to human life as such, as it is'. 'In this double function and ambivalence of literary reality, in this penetration to being, thanks to the description of a relatively arbitrarily chosen individual, we find the strangeness that is proper to literature' (Dresden 1997: 66). The more practical ethical direction includes contemporary authors who hold that literary reading enhances our imaginative ability or those who argue that 'literature is formative for the soul and thus for the happiness of human beings' (Brugmans 2009: 10).

It is clear that considerably more is expected along both lines-both the ontological and the ethical-than simply the illustration of a heterogenous or pre-given line of thought. To the contrary, literature will make its own irreducible contribution to the area of philosophy and worldviews. The question of meaning is posed in art and literature itself (explicitly or implicitly) and is answered there, in the form of a work of art, a poem, a novel, a composition.

\section{Research}

The perspective of research puts the greatest distance between us and the naive spiritual experience of art. It forces us to come to a critical relativization of what we have seen, heard, or read and also allows us to see that the presupposed 'immediacy' of our experience is in fact mediated by the schemas we learned but were no longer aware of. And which, in the detachment of our observation of all kinds of things, as well as norms we have unconsciously absorbed, also have an effect. In the work of art, as I wrote above, I meet an Other who addresses me. But is the Other right? Does he intend the best for me, not wanting to tempt me (as it were, behind my back) into a xenophobic or sexist way of looking and thinking? And do I not need critical theories to see through that, theories that bring my attention to my unconscious prejudices and help me to analyze them? I think that we do indeed need such theories. At the same time, it is essential that this criticism does not signify the end of the energy of the original experience of art, for that would mean the end of true life and true viewing. It comes down in the end-to use a much quoted expression by Paul Ricoeur (1913-2005) - to having the first naivete make way for a second naivete. The latter, having become wiser as a result of the critique, learns in a certain sense to read in an even more detached way. 
After this critical phase, research can pay due attention to questions directed more positively to the connection between art and the attribution of meaning. I will treat the question of why it is meaningful to research this connection in this final section-by again concentrating on literature. ${ }^{4}$

The primary reason for taking the question of the meaning of literature seriously is that narrativity and literature in themselves are a way of attributing meaning. With the terms 'meaning' and 'attribution of meaning', I am not thinking of concrete forms of this. Meaning can be attributed in all kinds of, possibly also undesirable, ways. Ricoeur, whom we just mentioned above, wrote about the conceivable variations that literature tries out on reality. In line with what myths and folk tales traditionally did, literature also creates distance between fact and meaning, between what is real and what it means in the experience of people. For what must be interpreted in a text is a proposed world that I could inhabit and wherein I could project one of my ownmost possibilities' (Ricoeur 1991: 86).

The diverse lines of his narrative theory come together in this single sentence. The theory explains why stories can be viewed as the nucleus of attributing meaning. In a short outline, the theory connects the different temporal dimensions with each other, concentrated in the intangible present; it creates identities—of things, animals, people in changing configurations; and it offers the reader the possibility of determining his own place and identity in the world of the text. Ricoeur emphasizes that it concerns the projection of possibilities-a formulation that derives from Aristotle. The true reader does not seek and consume any so-called facts and certainties but gropes for possibilities. In fact, that guarantees him or her freedom and dignity. Readers are not carried along and overwhelmed without offering resistance. And the Other of the text also remains intact in this new proximity, 'a proximity which suppresses and preserves the cultural distance and includes the otherness within the ownness.

The second reason to ask about the ability of literature and art to attribute meaning is in line with what has just been stated but offers more content. Just like myths and holy books, literature, and art can also be approached as sources of worldviews. Theologians and philosophers throughout the ages have sought inspiration or confirmation in the work of poets and writers or have themselves used-whenever that proved unavoidableliterary means. But literary theorists who made this connection were not lacking either. One of the authors worth mentioning here is Northrop Frye. From the beginning, Frye (who, to be sure, was originally a theologian) was looking for a coherent pattern in the myths that shape our lives. With a view to that, he researched the mythology of the Bible and our literary her- 
itage in successive studies. In Words with Power (1991) he presented a synopsis of the insights he discovered by means of the core metaphors of the mountain, the garden, the cave, and the oven. In his view, they mark the crystallization points of an imagined cosmos between the objective natural and the subjective psychological realities but with its own irreducible reality (Frye 2008: 16).

The concept of a cosmos built up by the imagination goes rather far. There are also examples of more modest research projects that concentrate on, for example, the problem of Islamism in the novels of Abdelkader Benali, or on the theme of substitution in the work of Shusaku Endo. ${ }^{5}$ The reflections of Erich Auerbach on the style differences between the Genesis story of the sacrifice of Isaac on the one hand and a passage from the nineteenth book of Homer's Odyssey on the other continue to be yet another example. The literary comparison brings him to a closely formulated thesis concerning the two styles that are said to have formed our culture. In Homer, the uniform presentation of everything-primary and secondary matters, the eternal and the internal-in what is written is striking, as is the story's lack of ambiguity and the little attention paid to internal problems. In the Old Testament, in contrast, Auerbach is struck by the chiaroscuro, the multiplicity, the internal layers and conflicts (Auerbach 1953: 11-12).

I would like to add to this that philosophers and theologians can benefit from a literary turn in their thinking and speaking. They strive by training for an ordered argument and simple conclusions, even when they are studying homo sapiens, that creature that is ruled by irresolvable tensions and contradictions. In distinction from this, the power of literature lies precisely in its ability to make a detailed and relativizing contribution. By giving expression to the religious in a poetic way, literature reinforces the 'density of reality' found in religious language, ${ }^{6}$ by submitting it to a narrative cohesion, it promotes - to use a key term from Musil-the 'accuracy' of the theological or philosophical argument.

As a third reason, I will cite the moral function that reading and viewing have. By this I do not mean that reading and viewing as such makes us better people. What I do mean is that we can enhance our insight into the possibilities of existence and our ability to have empathy for others by reading and viewing well. Traditionally, narrative art in particular has always seen and appreciated this. That is already apparent from the fact that morality is often embedded in narrative traditions that portray moral dilemmas and describe examples of virtue. But literary fiction and the visual arts can-as underscored by Wayne Booth, Richard Rorty, and Martha Nussbaum- 
provide a particular contribution of their own to the formation of morality. They are able to increase our sensitivity to the way other people think and experience the world. In this way, they can perhaps reinforce our empathic abilities and our solidarity with others. In her recent book, The Monarchy of Fear (2018), Martha Nussbaum describes how the United States has become trapped in the grip of fear by the presidency of the self-styled 'extremely stable genius' Donald Trump: fear of everything and everyone that is different. She provides shocking examples of the emotions that accompany that: disgust, envy, sexism, and misogyny. ${ }^{7}$ To illustrate what literature can do in such a situation, she quotes from a 2017 speech given by the Israeli novelist, David Grossman. Grossman says that writing “"offers the possibility of touching infinity" - not some heavenly infinity but ... the endless possibilities and ways of being inside life".' And he describes how he himself overcame his writer's block when writing the novel To the End of the Land (2008) by understanding that it was not his main character, Ora, "who had to submit to him but I who had to submit to her. In other words, I had to stop resisting the possibility of Ora inside me' (Nussbaum 2018: 245-246).

At first glance, this approach is appealing. Undoubtedly, many lovers of art and literature can produce their own personal examples, but some reservation should be exercised. Liesbeth Korthals Altes correctly commented that taking the ethical function of art seriously does not require a balanced view or a simple determination of a moral stance. Works of art can also fulfil this role 'through the fact that the reader or viewer performs the ethical work himself, is stimulated in his or her own words, challenged to determine where the boundary of the acceptable lies for him or her' (Korthals Altes 2001: 17). The effect of works of art resembles, in this respect, what can happen in the moral communication between people. Just like people, works of art can inspire us by examples of moral courage and selflessness. But they can also stimulate us to moral reflection by moving us, confusing us, amazing us, shaking up our rules, unmasking our hypocrisy.

\section{Conclusion}

I will conclude this article, but not with a conclusion that gives us a finished image of the spiritual experience of art. In the introduction I used the image of the delta, in which a number of streams find their own path, sometimes run parallel to each other, and sometimes flow together, sometimes separately. The second section confirmed that by emphasizing the transcending of meanings in art and religion, the fact that such meanings are both present and absent at the same time and withdraw from our striving 
for identification and definitions. The third section showed that research into that aspect of works of art as attributing meaning is indeed possible and meaningful, but there is every reason for continuing criticism and selfcriticism. It comes down to simultaneously being open to the truth that the work of art reveals and remaining aware of what is conventional and biased in our way of looking and seeing. Both in religion and in art, as I wrote earlier, an open and questioning attitude is needed: both resist the premature establishment of meanings. And the establishment is always premature. As far as I am concerned, that is perfectly articulated by Rutger Kopland in his poem 'I cavalli di Leonardo', on Leonardo da Vinci's sketches of horses. The visual arts and poetry-and, for my part, I am adding religion and theology-agree in this respect.

All those sketches he left behind-

endless series of repetitions: bunches of muscles, sinews,

knuckles, joints, the entire machinery

of driving-belts and levers with which

a horse moves,

and out of thousands of hair-thin little lines, the skin

almost invisibly gently disappearing into the paper

of ears and eyelids, nostrils

skin of the soul-

he must have wanted to find out how a horse

is made and have realized

it can't be done,

how the secret of a horse grew and grew

beneath his pencil.

Made the most splendid designs, studied them, discarded them.

(Kopland 2001: 49)

\section{Bibliography}

Auerbach E (1953) Mimesis: The Representation of Reality in Western Literature. Princeton: Princeton University Press. (Original German edition, 1946.)

Brugmans E (2009) De ziel in de literatuur. Nijmegen: Valkhof Pers.

Coenradie S (2016) Vicarious substitution in the literary work of Shūsaku Endō:

On fools, animals, objects and doubles. Utrecht.

Dresden S (1997) Het vreemde vermaak dat lezen heet: Een keuze uit de essays.

Amsterdam: Meulenhoff. 
Frye N (2008) Words with Power. Being a Second Study of 'the Bible and Literature'. Collected Works 26. Toronto: University of Toronto Press.

Gorringe TJ (2011) Earthly Visions: Theology and the Challenges of Art. New Haven and London: Yale University Press.

Goud J (2011) 'The finder hasn't looked properly'-Tensions between spirituality and truthfulness. In Hense E and Maas F (eds) Towards a Theory of Spirituality. Leuven: Peeters.

Goud J, ed (2011) Het leven volgens Arnon Grunberg: De wereld als poppenkast, Kampen-Kapellen: Klement en Pelckmans.

Kopland R (1995) Het mechaniek van de ontroering. Amsterdam: Van Oorschot.

Kopland R (2001) Memories of the Unknown. Translated from the Dutch and with an Introduction by James Brockway, with a Foreword by J. M. Coetzee. London: The Harvill Press.

Korthals Altes L (2001) 'Blessedly post-ironic'? Enkele tendensen in de hedendaagse literatuur en literatuurwetenschap. Inaugural Lecture. Groningen: Groningen.

Maas F (2009) Muzische verleidingen en het religieuze. In Wiegers G and Brugmans E (eds) Onverwachte impressie: Hedendaagse kunst en spiritualiteit. Nijmegen: Valkhof.

Moenandar S-J (2013) Depraved Borderlands: Encounters with Muslims in Dutch Literature and the Public Debate. Frankfurt a/M: PL Academic Research.

Nussbaum M (2018) The Monarchy of Fear: A Philosopher Looks at Our Political Crisis. New York: Simon \& Schuster.

Ricoeur P (1976) Interpretation Theory: Discourse and the Surplus of Meaning. Fort Worth: Texas Christian University Press.

Ricoeur P (1991) From Text to Action: Essays in Hermeneutics, II. Translated by Kathleen Blamey and John B. Thompson. Evanston: Northwestern University Press.

Sherry P (2007) Art and Literature. In Buckley J et al. (eds) The Blackwell Companion to Catholicism. Oxford: Blackwell.

Stoker W (2019) God opnieuw verbeeld: Een theologische kunstbeschouwing. Almere: Parthenon. 